\section{- \\ American Innovation and Competitiveness Act becomes law becomes law}

$I^{\mathrm{n}}$ $n$ the waning hours of the 114th US Congress, the American Innovation and Competitiveness Act (AICA) was passed by both the Senate and the House of Representatives and sent to the president's desk. On January 6, 2017, just a few weeks before his term ended, President Barack Obama signed the AICA into law (Pub. L. 114-329). The enactment of the AICA is of significance to the materials community because it updates policy guidelines for the National Science Foundation (NSF), National Institute of Standards and Technology, and the White House Office of Science and Technology Policy, as well as for many of the programs that drive and fund basic sciences research and science, technology, engineering, and mathematics (STEM) education.

The AICA's six sections, called "Titles"-_(I) maximizing basic research, (II) reducing administrative and regulatory burdens, (III) STEM education, (IV) leveraging the private sector, (V) manufacturing, and (VI) innovation and technology transfer-include several mandates that directly impact the materials community. Among them is a requirement, found in Title II, to establish an interagency working group responsible for developing a simplified and uniform grant format and a centralized researcher database to be used across all relevant federal agencies. The focus of the working group is to reduce administrative burdens while also protecting public interests such as transparency and accountability for federally funded research.

Title II also directs the heads of the federal science agencies to implement revised policies on attendance at scientific and technical workshops. This follows revisions to the Office of Management and Budget's guidelines on scientific conferences and should help minimize administrative burdens to ensure participation of federally funded scientists at conferences.

A third mandate of interest from Title II is the creation of a body within the National Science and Technology Council that must identify and coordinate opportunities for international cooperation on science and technology. This recognizes the increasingly global nature of scientific research, and seeks to establish collaborations and partnerships that can benefit US science and technology.

Also of specific note, the AICA expresses the sense of Congress that "underrepresented populations are the largest untapped STEM talent pools in the United States" and includes several mandates that focus on promoting inclusion and broadening participation in STEM fields (Title III). This is in line with many efforts within the science community to promote diversity and inclusion both at the student and professional level.

Lastly, the final three sections of the bill include provisions to allow greater flexibility in prize competitions, to encourage the agencies to use crowdsourcing and citizen science to fulfill their missions, to extend manufacturing partnerships with the private sector by changing the cost share to $50 \%$, and to provide continued support for commercialization of federally funded research. The extension of the Innovation Corps (I-Corps) Program (reported in the May 2016 issue of MRS Bulletin), mandated in Title VI, will likely have an impact on the materials science community because now researchers, students, and institutions funded by agencies other than the NSF can also participate in the innovative I-Corps Program, which focuses on both entrepreneurship and moving technologies from the laboratory into the marketplace.

Hailed as a bipartisan successor to the America COMPETES Act (i.e., Creating Opportunities to Meaningfully Promote Excellence in Technology, Education, and Science), the AICA is the product of negotiations between the Senate and the House that reconciled differences between the Senate bill (S. 3084) and the House's America COMPETES Reauthorization Act of 2015 (H.R.1806). The two bills, reported in the September 2016 issue of MRS Bulletin, differed in several important ways, and prior to negotiations were characterized as "miles apart" by Representative Eddie Bernice Johnson (D-Texas), Ranking Member of the House Science Committee.

Passage of the AICA came as a surprise to many because of both the significant differences between the bills and the timing of passage. The Senate only managed to negotiate a version of the AICA that could garner the necessary support in both chambers of Congress and the White House after most members of the House had already gone home for the year. The Senate passed the modified version on December 10 by unanimous consent, and Senators John Thune (R-S.D.) and Bill Nelson (D-Fla.), the Chair and Ranking Member of the committee that originated the bill (Senate Committee on Commerce, Science, and Transportation), released a statement expressing plans to pursue it again in 2017. But in a surprise move, the House also passed the AICA by unanimous consent on December 16, sending it to the president's desk before the end of 2016 .

While this process of passage is not unheard of, it was unexpected. "The science community believed that this bill would be taken up next Congress [the following year]," says Damon Dozier, Director of Government Affairs for the Materials Research Society. Reintroduction of the bill would require a renewed effort within the science community to push for a similarly pro-science bill, "but fortunately, in the final hours it was passed and sent to the president's desk," adds Dozier.

Given the wide disparity between the original Senate version of the AICA and 
the House's COMPETES legislation, the final version of the bill contains several compromises and lacks the audacious goal-namely, to double the basic sciences research budget - of the original COMPETES legislation. In fact, funding authorizations were left completely out of the final version of the AICA because incorporating funding levels was expected to have derailed unanimous consent in the House, and may also have upset unanimous consent in the Senate where offsetting increased authorizations has become an expected procedure. But despite these compromises, the bill is much closer to the widely supported Senate version and lacks the provisions from the House's COMPETES bill that were most strongly opposed by the science community.

Indeed, nearly 50 letters and statements from the science community (e.g., professional societies and associations, universities and institutes, and coalitions and consortiums) were submitted in opposition to the House's COMPETES bill, and the overwhelming concern in each stemmed from funding authorizations. From steep cuts in some budgets, to flat funding in others, and complete elimination of some programs, it was clear that the funding levels authorized in the House bill would prove detrimental to the health of US science and technology, according to those who opposed these mandates. In addition, rather than following recent protocol and setting an overall budget for the NSF, the House's version of COMPETES set specific funding levels for each of the NSF directorates. This move was widely opposed and viewed within the science community as a means to prioritize certain areas over others.

Another of the most broadly opposed provisions in the House version of the bill required adding a provision for "national interest" to the peer review criteria for evaluating grant proposals within the NSF. Conversely, the Senate version of the bill expressed support for the current peer review process that is based on intellectual merit and broader impacts. The final version of the bill reached a compromise by leaving the current peer review process intact but adding that the existing criteria should assure that the NSF's "activities are in the national interest" and by updating several of the goals that define the broader impacts criterion to include specific reference to the US or the American people.

The remainder of the AICA generally follows the bipartisan Senate version of the bill that was crafted by Senators Cory Gardner (R-Colo.) and Gary Peters (D-Mich.) and informed by a series of roundtable discussions with members of the science community. Unlike the original COMPETES legislation, the AICA does not update policy for the Department of Energy because those provisions were rolled into the a comprehensive energy policy bill (S. 2012) that passed both the Senate and House, but could not clear the final hurdle to resolve differences and died with the end of the 114th Congress.

"While the AICA is not as groundbreaking as the original COMPETES legislation, it is a true bipartisan effort to update US research and STEM education policy," says Dozier. "It was good to see Congress work together to pass this bill, and I hope that this is a good sign for the future - that Congress will work together for the best interests of the science community."

Jennifer A. Nekuda Malik
EU companies' R\&D investment grows faster than global and US trends

$\mathrm{T}_{\mathrm{l}}^{\mathrm{h}}$ e "2016 EU Industrial R\&D Investment Scoreboard," published by the European Commission, shows that EU companies invested $€ 188.3$ billion in R\&D in fiscal year 2015/2016. This constitutes an annual increase of $7.5 \%$, which puts EU companies ahead of the global $(6.6 \%)$ and US (5.9\%) trends.

Global industrial R\&D investment reached $€ 696$ billion worldwide, with sectors such as software, information technology (IT), pharmaceuticals, and automobiles fostering R\&D investments and sales. Overall sales, however, declined $3.6 \%$ worldwide, mostly due to the performance of low-tech sectors, particularly oil and mining, which suffered from low commodity prices.
Thirty EU companies are among the world's top $100 \mathrm{R} \& \mathrm{D}$ investors, mainly in the fields of automobiles, pharmaceuticals and biotechnology, information communications technology, and aerospace and defense. The top investors are based in Germany (€69.8 billion), France (€28.5 billion), the UK (€28.2 billion), and The Netherlands ( $€ 14.1$ billion).

Asian companies showed the highest increases in R\&D, especially those based in China (up by $24.7 \%$ to $€ 49.8$ billion), although their sales decreased as well. Globally, the software sector showed the highest year-on-year growth in R\&D, of $12.3 \%$, followed by pharmaceuticals $(9.8 \%)$, IT hardware (7.6\%), and automobiles (6.7\%).
The Scoreboard is accompanied by a survey of the 1000 top R\&D investors based in the EU. It shows that R\&D investments are expected to fall in the coming years in the automobile and parts sector $(-0.8 \%)$ while growth of $7-8 \%$ is expected in high-tech sectors, specifically in health care, pharmaceuticals, and technology hardware.

The "EU Industrial R\&D Investment Scoreboard," published annually by the European Commission (DG Research \& Innovation and DG Joint Research Centre) collects companies' key R\&D and economic indicators. The 2016 edition reviews the performance of the top $2500 \mathrm{R} \& \mathrm{D}$ investing companies in the world, which account for around $90 \%$ of the total R\&D financed by business. A focus on the top $1000 \mathrm{R} \& \mathrm{D}$ investors in the EU is also included. The Scoreboard is accompanied by the "2016 EU Survey on Industrial R\&D Investment Trends." 